\title{
Photoelectrochemical Cells based on Emeraldine Base Form of Polyaniline
}

\author{
Assefa Sergawie, ${ }^{*, \#, a}$ Teketel Yohannes, ${ }^{b}$ Serap Günes, ${ }^{a}$ Helmut Neugebauer ${ }^{a}$ and Niyazi S. Sariciftci ${ }^{a}$
}

${ }^{a}$ Linz Institute for Organic Solar Cells (LIOS), Physical Chemistry, Johannes Kepler University Linz, Altenbergstraße 69, A-4040 Linz, Austria

${ }^{b}$ Department of Chemistry, Addis Ababa University, P.O.BOX 1176, Addis Ababa, Ethiopia

\begin{abstract}
Células fotoeletroquímicas (PECs) têm sido fabricadas usando a forma base esmeraldina de polianilina (EB) como um material fotoativo e o par redox $\mathrm{Eu}^{2+} / \mathrm{Eu}^{3+}$ em metanol como eletrólito. Uma célula fotoeletroquímica com a estrutura: Vidro/ITO/ EB:Nc-TiO $/$ /Eletrólito/ Pt produz uma voltagem de circuito-aberto $\left(V_{O C}\right)$ de $-0,132 \mathrm{~V}$ e uma corrente de curto-circuito $\left(I_{S C}\right)$ de $0,64 \mu \mathrm{A} \mathrm{cm}^{-2}$ sob $50 \mathrm{~mW} \mathrm{~cm}{ }^{-2}$ de iluminação com luz branca de lâmpada de Xe. Num esforço para aumentar a foto-resposta, uma PEC com estrutura: Vidro/ITO/ EB:Nc-TiO/ Eletrólito/Pt foi construída, na qual um filme composto de $\mathrm{EB}$ e $\mathrm{TiO}_{2}\left(\mathrm{Nc}-\mathrm{TiO}_{2}\right)$ nanocristalino é usado como material fotoativo. A célula mostra uma $V_{O C}$ de $-0,205 \mathrm{~V}$ e uma $I_{S C}$ de $105 \mu \mathrm{A}$ $\mathrm{cm}^{-2}$ quando iluminada sobre as mesmas condições.
\end{abstract}

Photoelectrochemical cells (PECs) have been fabricated using the emeraldine base form of polyaniline (EB) as a photoactive material and $\mathrm{Eu}^{2+} / \mathrm{Eu}^{3+}$ redox couple in methanol as an electrolyte. A PEC with a structure: Glass/ITO/EB/electrolyte/Pt produces an open-circuit voltage $\left(V_{O C}\right)$ of $-0.132 \mathrm{~V}$ and a short-circuit current $\left(I_{S C}\right)$ of $0.64 \mu \mathrm{A} \mathrm{cm}^{-2}$ under $50 \mathrm{~mW} \mathrm{~cm} \mathrm{~cm}^{-2}$ white light illumination from Xe lamp. In an effort to increase the photoresponse, a PEC with a structure: Glass/ITO/EB:Nc-TiO,/Electrolyte/Pt has been devised in which a composite film of EB and nanocrystalline $\mathrm{TiO}_{2}\left(\mathrm{Nc}^{-\mathrm{TiO}_{2}}\right)$ is used as a photoactive material. The cell shows a $V_{O C}$ of $-0.205 \mathrm{~V}$ and an $I_{S C}$ of $105 \mu \mathrm{A} \mathrm{cm} \mathrm{cm}^{-2}$ when illuminated under the same conditions.

Keywords: emeraldine base form of polyaniline, nanocrystalline $\mathrm{TiO}_{2}, \mathrm{Eu}^{2+} / \mathrm{Eu}^{3+}$ redox couple, photoelectrochemical cell

\section{Introduction}

The need for inexpensive, renewable energy sources has led to the development of photovoltaic cells based on organic molecules and conjugated polymers. ${ }^{1-3}$ For such applications, stable photoactive materials that absorb light in the longer wavelength region of the solar spectrum are required. Polyaniline (PAni) is such material, whose absorption can be switched to the longer wavelength region of the solar spectrum. ${ }^{4}$ Different researchers have studied the photoelectrochemical properties of PAni. Kaneko and Nakamura ${ }^{5}$ reported that a PAni film gives a cathodic photocurrent response at negative applied potentials $(v s . \mathrm{Ag} / \mathrm{AgCl})$ and a low anodic photocurrent response at positive

*e-mail: Assefaserg@yahoo.com

\#Present Address: Department of Chemistry, Addis Ababa University, P.O. Box 1176, Addis Ababa, Ethiopia. Tel.: +251911487557 applied potentials when dipped into an aqueous electrolyte solution $(\mathrm{pH}=6)$ containing $\mathrm{LiClO}_{4}$. The catalytic effect of PAni on the photoelectrochemical reductions of chloral in $\mathrm{NH}_{3} / \mathrm{HF}$ solution and of potassium peroxodisulphate in aqueous $\mathrm{H}_{2} \mathrm{SO}_{4}$ solution has also been investigated. ${ }^{5,6}$ Based on these preliminary investigations, PAni was considered as a $p$-type semiconductor that can be useful for the photoelectrochemical conversion of light to electricity and for photoassisted electrosynthesis. The effect of redox couples on the photoelectrochemical behavior of PAni at different applied potentials (between $-0.2 \mathrm{~V}$ and +0.8 $\mathrm{V} v$ s. SCE) has been studied by Shen and Tian. ${ }^{7}$ It was observed that the redox couples $\left(\mathrm{Fe}(\mathrm{CN})_{6}{ }^{3-} / \mathrm{Fe}(\mathrm{CN})_{6}{ }^{4}\right.$ and $\mathrm{I}_{2} / \mathrm{I}^{-}$increase the magnitude and the stability of the photocurrent in aqueous acidic media. In an effort to increase the photoresponse of PAni, PAni had been electropolymerized on cellulose acetate-coated $\mathrm{Pt}$ electrode. ${ }^{8}$ The porous structure of cellulose acetate 
membrane favored the swelling of the film thereby increasing the surface area of the conductive PAni exposed to the electrolyte solution. This has been reported to intensify the process of charge transfer and mass transport during the cyclic voltammetry of PAni under illumination with concomitant increment in the photocurrent.

The emeraldine base form of polyaniline (EB) has been used as a hole transporting material in solid-state dye-sensitized $\mathrm{TiO}_{2}$ solar cells. ${ }^{9} \mathrm{~EB}$ that is protonated with different acids has been investigated as a holetransporting layer in polymer light emitting diodes, as a photoactive layer in Schottky diodes, and as a sensitizer for nanocrystalline $\mathrm{TiO}_{2}\left(\mathrm{Nc}-\mathrm{TiO}_{2}\right)$ film in the presence of $\mathrm{KI} / \mathrm{I}_{2}$ in an aqueous electrochemical cell and in a solidstate photoelectrochemical cell (PEC). ${ }^{10-13}$ In the later case the device consists of EB doped with dodecylbenzene sulphonic acid and blended with ethylene-propylene-diene terpolymer as a working electrode, poly(ethyleneoxide-co-epichlorohydrine)/ $\mathrm{NaI}_{2}$ as a polymer electrolyte and $\mathrm{Pt}$ as a counter electrode. According to the report, the $V_{O C}$ of the device was zero both in the dark and under illumination while a cathodic current was observed in the dark at negative applied potentials, the magnitude of which increased under illumination.

There has been no report on the photovoltaic effect of EB in a liquid-state PEC. In this paper we report on the properties of PECs that consist of EB as a photoactive material and $\mathrm{Eu}^{2+} / \mathrm{Eu}^{3+}$ redox couple in methanol as an electrolyte.

\section{Experimental}

\section{Preparation of $\mathrm{Nc}-\mathrm{TiO}_{2}$ film electrode}

Sheets of indium-doped tin oxide coated glass (ITOglass), each of dimension $4.5 \times 0.8 \mathrm{~cm}$, were cleaned successively with toluene, acetone and isopropyl alcohol and dried in air. A colloidal solution of $\mathrm{Nc}^{-\mathrm{TiO}_{2}}$ was prepared by the hydrolysis of titanium tetraisopropoxide following a literature procedure. ${ }^{14}$ Accordingly, $0.5 \mathrm{~mL}$ titanium tetraisopropoxide (Aldrich, 99\%) was slowly added with stirring to a mixture of $2.5 \mathrm{~mL}$ glacial acetic acid (Sigma Aldrich), $7.5 \mathrm{~mL}$ isopropanol (Sigma Aldrich) and $2.5 \mathrm{~mL}$ deionized water. The solution was stirred till a viscous solution was formed. The viscous solution was coated on ITO-glass by doctor blading and sintered at $450{ }^{\circ} \mathrm{C}$ for half an hour. A non-coated area of the ITOglass was left at the edge of the longer side for electrical contact.

\section{Preparation of polyaniline}

Cyclic voltammetry was used to prepare PAni in a three-electrode electrochemical cell. The working electrodes used were ITO-glass and ITO-glass coated with $\mathrm{Nc}-\mathrm{TiO}_{2}$. The reference and the counter electrodes were saturated calomel electrode (SCE) and Pt foil, respectively. The potential range used was between $-0.15 \mathrm{~V}$ and +0.9 V. The potential was applied with a Jaissle Potentiostat/ Galvanostat 1030PC.T. The polymerization was carried out in a solution of $1.0 \mathrm{~mol} \mathrm{~L}^{-1}$ aqueous $\mathrm{HClO}_{4}$ (Fluka), $0.1 \mathrm{~mol} \mathrm{~L}^{-1} \mathrm{NaClO}_{4}$ (Fluka) and $0.1 \mathrm{~mol} \mathrm{~L}^{-1}$ freshly distilled aniline (Fluka). The solution was purged with argon for 20 min before polymerization and remained under argon atmosphere throughout the polymerization process. PAni was initially prepared in its emeraldine salt form by holding the potential at $0.4 \mathrm{~V}$. The EB was prepared by treating the emeraldine salt with excess $25 \% \mathrm{NH}_{3}$. The blue EB was then dried under nitrogen. Its UV-Vis absorption spectrum on ITO-glass was measured by Hewlett Packard 8453 spectrometer.

\section{Photoelectrochemical studies}

For photoelectrochemical studies, EB and a composite of $\mathrm{EB}$ and $\mathrm{Nc}^{-\mathrm{TiO}_{2}}$ on ITO-glass were used as photoactive materials. $0.02 \mathrm{~mol} \mathrm{~L}^{-1} \mathrm{EuCl}_{2}$ (Aldrich) and $0.02 \mathrm{~mol} \mathrm{~L}^{-1}$ $\mathrm{EuCl}_{3}$ (Aldrich) in methanol (Baker) were used as a redox couple. EB did not show a photoresponse in the presence of $\mathrm{KI} / \mathrm{I}_{2}\left(\mathrm{E}^{\mathrm{o}}=0.53 \mathrm{~V} v s\right.$. NHE). This may be due to a mismatch in the energy positions between the redox couple and the highest occupied molecular orbital of EB. Because of this, the redox couple $\mathrm{Eu}^{2+} / \mathrm{Eu}^{3+}\left(\mathrm{E}^{\mathrm{o}}=-0.36 \mathrm{~V} v\right.$. $\left.\mathrm{NHE}\right)$ was chosen as electron mediator. Methanol was used as a solvent to avoid the protonation of EB and because both $\mathrm{EuCl}_{2}$ and $\mathrm{EuCl}_{3}$ are soluble in it. The photoactive electrode and the Pt counter electrode immersed in a cuvette that contains the electrolyte solution formed the PEC.

The light source was a Xe arc lamp (Schoeffel). The intensity of the white light used for current-voltage studies was $50 \mathrm{~mW} \mathrm{~cm}^{-2}$ (measured by a power meter Lasermate A, model LD-3, USA) without corrections for the absorption and scattering by the cuvette. Current-voltage curves were measured using Keithley 2400 source meter at constant applied potentials (for EB-based cell) and during potential scans at a rate of $5 \mathrm{mV} \mathrm{s}^{-1}$ (for EB:Nc$\mathrm{TiO}_{2}$-based cell). The device was illuminated from the solution/polymer interface side. The photocurrent action spectra were studied using a monochromator (Schoeffel) fitted to the Xe arc lamp. $345 \mathrm{~nm}$ and $520 \mathrm{~nm}$ filters were used during the measurement in the range 380 to $540 \mathrm{~nm}$ 
and in the range from 550 to $800 \mathrm{~nm}$, respectively. All measurements were made when the open-circuit voltage came to a steady state.

\section{Results and Discussion}

\section{Current-voltage characteristics}

\section{Polyaniline grown on ITO-glass electrode}

Figure 1 illustrates the surface morphology of EB film on ITO-glass as determined by atomic force microscope (AFM) in contact mode.

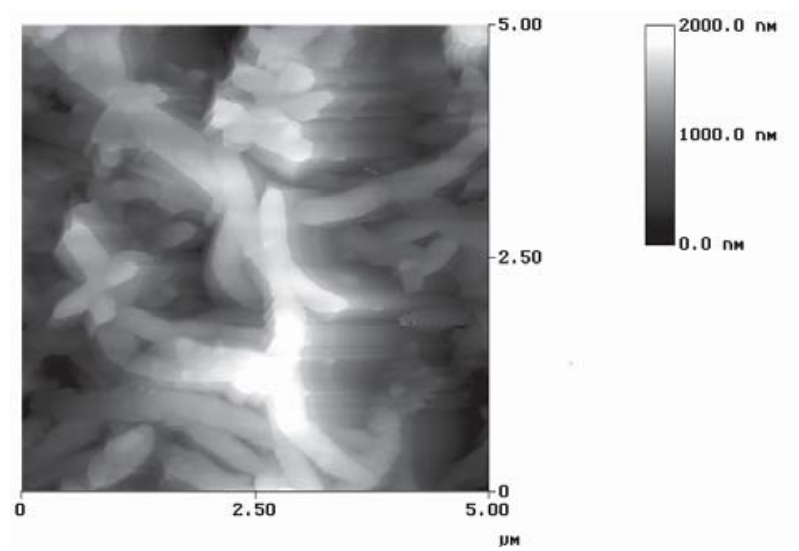

Figure 1. AFM picture of EB film on ITO-glass.

The film grew in bundles of fibers and its average thickness, as determined by scanning electron microscopy, was in the range 3-4 $\mu \mathrm{m}$. The PAni adhered poorly on the ITO-glass and its thickness was not uniform. Thick films detached rather easily while thin films showed a very weak photocurrent response. Figure 2 shows the current-voltage $(I-V)$ characteristics of the EB-based PEC in dark and under white light illumination with intensity of $50 \mathrm{~mW} \mathrm{~cm}^{-2}$. Illumination of the PEC produced an anodic current under short-circuit condition and the negative value of the $V_{O C}$ observed indicates that the photoactive electrode is higher in energy than the counter electrode. The $V_{O C}$, the $I_{S C}$ and the fill factor $(F F)$ obtained under illumination were $-0.132 \mathrm{~V}, 0.64 \mu \mathrm{A}$ $\mathrm{cm}^{-2}$ and 0.35 , respectively. The dark current may be a result of an electrochemical reaction on the EB film that involves the redox couple. The $F F$ was calculated using equation 1 :

$$
F F=\frac{I_{P} V_{P}}{I_{S C} V_{O C}}
$$

where the product $I_{P} V_{P}$ is the maximum power delivered by the PEC under illumination.

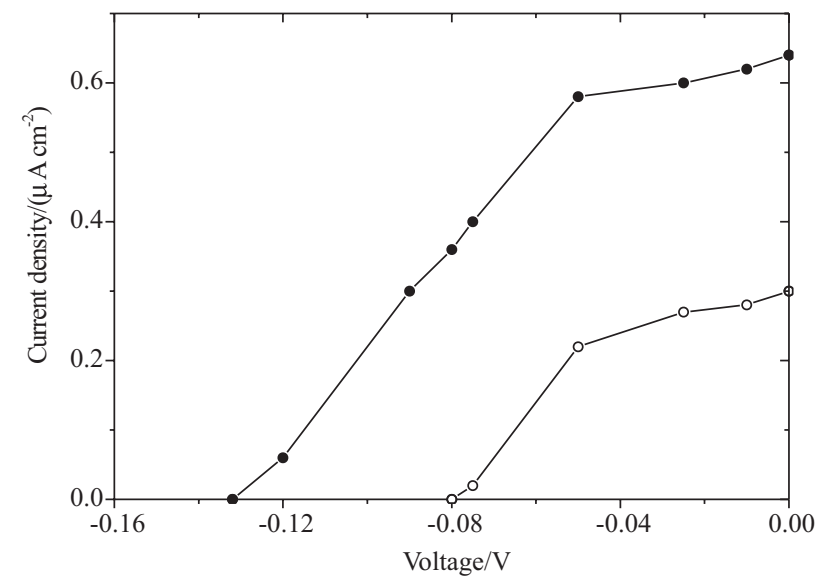

Figure 2. $I-V$ characteristics for the PEC, Glass/ITO/EB/Electrolyte/Pt, in dark (open circles) and under $50 \mathrm{~mW} \mathrm{~cm}^{-2}$ white light illumination from Xe lamp (closed circles). Electrolyte: $\mathrm{CH}_{3} \mathrm{OH}+0.02 \mathrm{~mol} \mathrm{~L}^{-1} \mathrm{EuCl}_{2}$ $+0.02 \mathrm{~mol} \mathrm{~L}^{-1} \mathrm{EuCl}_{3}$.

\section{Polyaniline grown on $\mathrm{Nc}$-TiO,-coated ITO-glass}

In an effort to increase the photoresponse of EB and its possible use to sensitize $\mathrm{TiO}_{2}$, aniline was electropolymerized on $\mathrm{Nc}_{-} \mathrm{TiO}_{2}$-coated ITO-glass. PAni started to grow on the ITO surface between the $\mathrm{Nc}-\mathrm{TiO}_{2}$ grains and extended to the surface. The electropolymerization process and the electrochromic properties of the PAni film were not affected by $\mathrm{TiO}_{2}$ except that the rate of formation was slower than that on a bare ITOglass. The PAni:Nc- $\mathrm{TiO}_{2}$ composite film adhered strongly to the ITO-glass. The average thickness of the composite film was $1 \mu \mathrm{m}$. Figure 3 shows the $I-V$ characteristics of the PEC, Glass/ITO/EB:Nc-TiO 2 /Electrolyte/Pt, in dark and under white light illumination with intensity of 50 $\mathrm{mW} \mathrm{cm}{ }^{-2}$.

Illumination of the PEC produced an anodic current under short-circuit condition and the negative value of

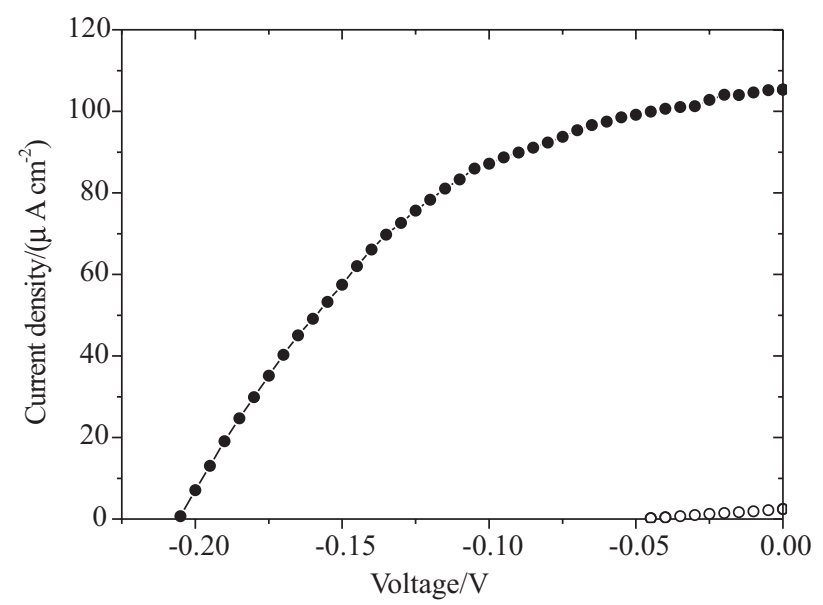

Figure 3. $I-V$ characteristics for the PEC, Glass/ITO/EB:Nc-TiO/Electrolyte/Pt, in dark (open circles) and under $50 \mathrm{~mW} \mathrm{~cm}^{-2}$ white light illumination from Xe lamp (closed circles). Electrolyte: $\mathrm{CH}_{3} \mathrm{OH}+0.02 \mathrm{~mol}$ $\mathrm{L}^{-1} \mathrm{EuCl}_{2}+0.02 \mathrm{~mol} \mathrm{~L}^{-1} \mathrm{EuCl}_{3}$. 
the $V_{O C}$ observed indicates that the photoactive electrode is higher in energy than the counter electrode. The cell has a $V_{O C}$ of $-0.205 \mathrm{~V}$, an $I_{S C}$ of $105 \mu \mathrm{A} \mathrm{cm} \mathrm{cm}^{-2}$ and a calculated $F F$ of 0.44 . The photoresponse of the PEC and its stability were more than the EB-based PEC.

\section{The photocurrent action spectra}

The photocurrent action spectrum for the EB:Nc-TiO based PEC is shown in Figure 4. The action spectrum for $\mathrm{Nc}_{-} \mathrm{TiO}_{2}$-based cell is also shown for comparison. The inset shows the UV-Vis absorption spectra of EB film. The maximum incident photon-to-current conversion efficiency (IPCE) for the EB: Nc- $\mathrm{TiO}_{2}$-based cell was $80 \%$. The high value corresponds to the absorption of light both by $\mathrm{EB}$ and $\mathrm{TiO}_{2}$ at $370 \mathrm{~nm}$. The IPCE due to absorption by $\mathrm{EB}$ at $700 \mathrm{~nm}$ was $8 \%$. The photoresponse of $\mathrm{Nc}-\mathrm{TiO}_{2}$ is negligible above $420 \mathrm{~nm}$. The IPCE \% is calculated using equation 2 :

$$
I P C E \%=\frac{1240 I_{S C}\left(\mu \mathrm{Acm} \mathrm{cm}^{-2}\right)}{\lambda(\mathrm{nm}) I_{\text {in }}\left(\mathrm{W} \mathrm{m}^{-2}\right)}
$$

where $\lambda$ is the excitation wavelength and $I_{\text {in }}$ is the incident photon intensity.

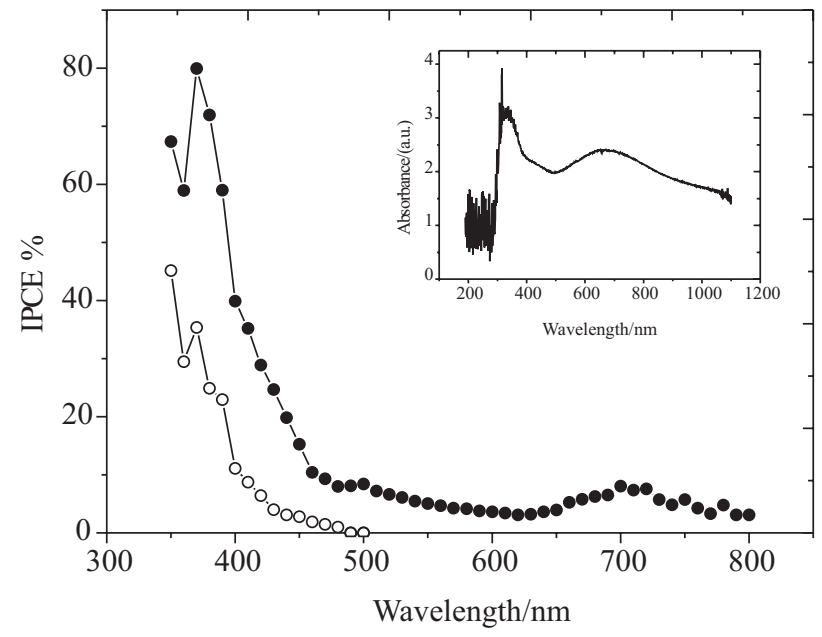

Figure 4. The photocurrent action spectra of the PECs Glass/ITO/EB:Nc$\mathrm{TiO}_{2} /$ Electrolyte/Pt (closed circles) and Glass/ITO/Nc-TiO $/$ Electrolyte/Pt (open circles). Electrolyte: $\mathrm{CH}_{3} \mathrm{OH}+0.02 \mathrm{~mol} \mathrm{~L}^{-1} \mathrm{EuCl}_{2}+0.02 \mathrm{~mol} \mathrm{~L}^{-1}$ $\mathrm{EuCl}_{3}$. Inset: UV-Vis absorption spectra of EB film on ITO-glass.

A schematic energy level diagram for the device: Glass/ITO/EB:Nc-TiO $/$ Electrolyte/Pt is shown in Figure 5. The onset potentials for oxidation ( $\left.\mathrm{E}^{\text {ox }}{ }_{\text {onset }}\right)$ and reduction ( $\mathrm{E}_{\text {red }}^{\mathrm{rot}}$ ) can be used to estimate the energies of the highest occupied molecular orbitals $\left(\mathrm{E}_{\text {номо }}\right)$ and the lowest unoccupied molecular orbitals $\left(\mathrm{E}_{\text {LUMO }}\right.$ ) of conducting polymers. ${ }^{15}$ According to de Leeuw et al., ${ }^{16} \mathrm{E}_{\text {номо }}(\mathrm{eV})=-\left(\mathrm{E}_{\text {onset }}^{\text {ox }}+4.4\right)$ and $\mathrm{E}_{\text {LUмо }}$
$(\mathrm{eV})=-\left(\mathrm{E}_{\text {onset }}^{\mathrm{red}}+4.4\right)$, where the onset potentials are in $\mathrm{V} v s$. SCE. Using cyclic voltammetry, $\mathrm{E}^{\text {ox }}{ }_{\text {onset }}$ and $\mathrm{E}_{\text {onset }}^{\text {red }}$ of the EB film were found to be $0.8 \mathrm{~V}$ and -0.6 $\mathrm{V} v s$. SCE, respectively. This yields an estimated energy level of $-5.2 \mathrm{eV}$ for the HOMO and $-3.8 \mathrm{eV}$ for the LUMO of EB. The position of $\mathrm{Eu}^{2+} / \mathrm{Eu}^{3+}$ redox system $\left(\mathrm{E}^{\mathrm{o}}=-0.36 \mathrm{~V} v s\right.$. NHE) is approximately at $-4.14 \mathrm{eV}$ $(0 \mathrm{~V} v s . \mathrm{NHE}=-4.5 \mathrm{eV})$.

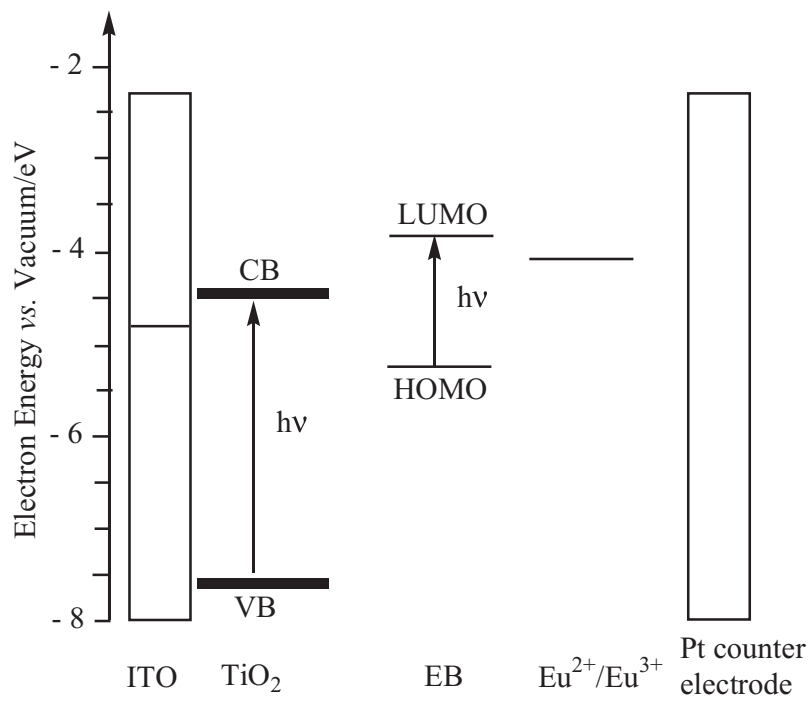

Figure 5. A schematic energy level diagram for the PEC: Glass/ITO/ EB:Nc-TiO $/$ Electrolyte/Pt. The excitation of EB at $700 \mathrm{~nm}$ is shown.

From the experimental results observed above, it is possible to suggest that EB shows photovoltaic effect in the presence of the $\mathrm{Eu}^{2+} / \mathrm{Eu}^{3+}$. An anodic photocurrent has been produced when a potential is applied between zero and the open-circuit voltage. This observation indicates that upon illumination, electrons from the HOMO of EB excite to its LUMO from which they are transferred to the ITO (in EB-based cell) or to the conduction band edge of $\mathrm{Nc}_{-} \mathrm{TiO}_{2}$ and then to the ITO (in $\mathrm{EB}: \mathrm{Nc}_{-}-\mathrm{TiO}_{2}$-based cell). In the mean time, holes can be transferred from $(\mathrm{EB})^{+}$to $\mathrm{Eu}^{2+}$. The $\mathrm{Eu}^{2+}$ is recovered at the counter electrode where $\mathrm{Eu}^{3+}$ accepts electrons from the external circuit. Such transfer of charges can however take place only if the Fermi energy levels of the ITO $(-4.7 \mathrm{eV})$ and the $\mathrm{Nc}^{-\mathrm{TiO}_{2}}(-4.4 \mathrm{eV})$ are raised to a level higher than the energy of the counter electrode, probably by pinning with the excited-state of EB. The $\mathrm{Nc}^{-T i O}$ film, in addition to its use as a matrix for the growth of PAni, participates in the light absorption (in the short wavelength region) and in the effective injection of electrons from the LUMO of the EB to the ITO contact. The photocurrent observed in the longer wavelength region is due to the absorption of light by EB. 


\section{Conclusions}

Photoelectrochemical cells have been fabricated using the emeraldine base form of polyaniline as a photoactive material in the presence of $\mathrm{Eu}^{2+} / \mathrm{Eu}^{3+}$. The photoresponse of EB: $\mathrm{Nc}_{-} \mathrm{TiO}_{2}$-based PEC is significantly higher than that of EB-based and $\mathrm{Nc}-\mathrm{TiO}_{2}$-based PECs. The EB/Nc-TiO based cell shows a $V_{O C}$ of $-0.205 \mathrm{~V}$ and an $I_{S C}$ of $105 \mu \mathrm{A}$ $\mathrm{cm}^{-2}$ under $50 \mathrm{~mW} \mathrm{~cm}{ }^{-2}$ white light illumination from a Xe lamp. The cell shows an IPCE of $80 \%$ and $8 \%$ at 370 $\mathrm{nm}$ and $700 \mathrm{~nm}$, respectively. Though the performances of the PECs under the present experimental conditions are low, the results indicate that we can make use of the high environmental stability of PAni for solar cell application.

\section{References}

1. Peumans, P.; Uchida, S.; Forrest, S.R.; Nature 2003, 425, 158.

2. Hagfeldt, A.; Grätzel, M.; Acc. Chem. Res. 2000, 33, 269.

3. Ma, W.; Yang, C.; Gong, X.; Lee, K.; Heeger, A.J.; Adv. Funct. Mater. 2005, 15, 1617.

4. Sariciftci, N.S.; Kuzmany, H.; Synth. Met. 1987, 21, 157.

5. Kaneko, M.; Nakamura, H.; J. Chem. Soc., Chem. Commun. 1985, 346.
6. Genies, E.M.; Lapkowski, M.; Santier, C.; Vieil, E.; Synth. Met. 1987, 18, 18.

7. Shen, P.K.; Tian, Z.Q.; Electrochimica Acta 1989, 34, 1611.

8. Das Neves, S.; De Paoli, M.-A.; Synth. Met. 1998, 96, 49.

9. Tan, S.X.; Zhai, J.; Wan, M.X.; Jiang, L.; Zhu, D.B.; Synth. Met. 2003, 137, 1511.

10. Higgins, R.W.T.; Zaidi, N.A.; Monkman, A.P.; Adv. Funct. Mater. 2001, 11, 407.

11. Chen, S.-An.; Fang, Y.; Synth. Met. 1993, 60, 215.

12. Hao, Y.; Yang, M.; Yu, C.; Cai, S.; Liu, M.; Fan, L.; Li, Y.; Sol. Energy Mater. Sol. Cells 1998, 56, 75.

13. Carinhana Jr., D.; Faez, R.; Nogueira, A.F.; De Paoli, M.-A.; Synth. Met. 2001, 121, 1569.

14. Tennakone, K.; Kumara, G.R.R.A.; Kottegoda, I.R.M.; Wijayantha, K.G.U.; Perera, V.P.S.; J. Phys. D: Appl. Phys. 1998, 31, 1492.

15. Cervin, R.; Li, X.C.; Spencer, G.W.C.; Holmes, A.B.; Moratti, S.C.; Friend, R.H.; Synth. Met. 1997, 84, 359; Liu, Y.; Liu, M.S.; Jen, A.K.-Y.; Acta Polym. 1999, 50, 105.

16. de Leeuw, D.M.; Simenson, M.M.J.; Brown, A.R.; Einerhand, R.E.F.; Synth. Met. 1997, 87, 53.

Received: February 22, 2007 Web Release Date: September 19, 2007 